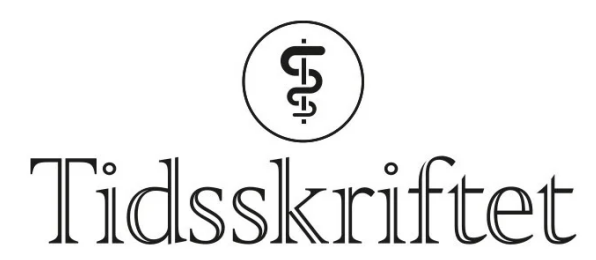

DEN NORSKE LEGEFORENING

\title{
Jernmangelanemi i Sørøst-Asia
}

\author{
VERDENS HELSE
}

KRISTOFFER BRODWALL

Email: kristoffer.brodwall@gmail.com

Ålesund sjukehus

\section{Jernmangelanemi er vanlig blant barn i Sørøst-Asia, men jerntilskudd og pro-/prebiotika kan redusere forekomsten.}

I India er over 75 \% av alle småbarn anemiske. En tverrsnittsstudie av 401 presumptivt friske indiske barn i alderen 12-23 måneder fra rurale strøk viste assosiasjon mellom anemi og hhv. hemoglobinopatier, folatmangel, maternell anemi, og familiens økonomi og mattilgang (1). Sterkest assosiasjon var det imidlertid med jernmangel, målt med lavt ferritinnivå. Vedvarende amming disponerte for jernmangel. I tillegg til anemi vil jernmangel kunne føre til manglende fysisk og kognitiv utvikling.

I en indonesisk studie av 81885 familier i rurale strøk og 26653 familier fra urban slum fant man lavere forekomst av anemi blant barna (6-59 måneder) hvis de fikk jernberiket melk. Resultatene var sammenliknbare i rurale og urbane områder (OR hhv. o,76 og o,79, $\mathrm{p}<\mathrm{o,0001}$ (2 2 . Man kunne ikke påvise en tilsvarende effekt av jernberikede nudler, men kombinasjonen av beriket melk og nudler var bedre enn beriket melk alene.

En annen lovende strategi kan være å påvirke tarmfloraen. En randomisert dobbeltblind studie fra New Dehli i India viste at 1-4 år gamle barn som fikk melk tilsatt probiotika (Bifidobacterium lactis) og prebiotika (oligosakkarid) i ett år hadde risikoreduksjon på $45 \%$ (95\% KI 11-66 \%, p = o,01) for jernmangel og anemi, sammenliknet med barn som fikk samme melk, men uten tilsetninger (3). Det var også en positiv effekt på veksten.

\section{LITTERATUR}

1. Pasricha SR, Black J, Muthayya S et al. Determinants of anemia among young children in rural India. Pediatrics 2010; 126: e140-9.

2. Semba RD, Moench-Pfanner R, Sun K et al. Iron-fortified milk and noodle consumption is associated with lower risk of anemia among children aged 6-59 mo in Indonesia. Am J Clin Nutr 2010; 92:170-6.

3. Sazawal S, Dhingra U, Hiremath G et al. Effects of Bifidobacterium lactis HNo19 and prebiotic oligosaccharide added to milk on iron status, anemia, and growth among children 1 to 4 years old. 
J Pediatr Gastroenterol Nutr 2010; 51:341-6.

Publisert: 7. oktober 2010. Tidsskr Nor Legeforen. DOI: 10.4045/tidsskr.10.0847

(C) Tidsskrift for Den norske legeforening 2023. Lastet ned fra tidsskriftet.no 26. april 2023. 